\title{
Нас информирунт
}

МОСИН Василий Иванович - кандидат философских наук, доцент; генеральный директор Тульского социологического центра (300001, Россия, г. Тула, ул. Гармонная, 28 оф. 39); старший научный сотрудник Центра региональных исторических исследований Тульского государственного педагогического университета им. Л.Н. Толстого (300026, Россия, г. Тула, пр-кт Ленина, 125, кopn. 4; mosin55@bk.ru)

\section{ВЗАИМОСВЯЗЬ ВЛАСТИ И БИЗНЕСА В ТУЛЬСКОЙ ОБЛАСТИ}

\begin{abstract}
Аннотация. В статье автор рассматривает взаимосвязь власти и бизнеса в Тульской обл. на примере вручения ежегодной региональной премии «Тульский бизнес». Во многих российских регионах приходится выстраивать разумное взаимоотношение бизнеса и власти. Такое взаимоотношение не должно навредить развитию бизнеса, а, наоборот, помочь ему развиваться на благо региона и России в целом. В 2011 г. в Тульской обл. была учреждена первая независимая премия в области бизнеса - «Тульский бизнес». Цель премии - подведение бизнес-итогов года, задача - выявить лучших и создать новый имидж компаний-участников. Региональная премия «Тульский бизнес» помогает привлекать инвестиции в тульскую экономику. Компаниям, принимающим в ней участие, выпадает уникальный шанс расширить свой бизнес, повысить репутацию и конкурентоспособность, причем не только на рынке Тульской обл., но и в России в целом.
\end{abstract}

Ключевые слова: взаимосвязь, бизнес, власть, премия

B любом российском регионе наверняка приходится ломать голову над разумным взаимоотношением власти и бизнеса. Делать это надо всегда осторожно, чтобы не только не навредить развитию бизнеса, но и помочь ему развиваться на благо региона и России в целом. В Тульской обл. нашли такой способ в виде ужреждения региональной премии «Тульской бизнес».

Региональная премия «Тульский бизнес» - это первая независимая премия в области бизнеса в Тульской обл., учрежденная в 2011 г. Цель премии - подведение бизнес-итогов года, задача - выявить лучших и создать новый имидж компаний-участников. Премия «Тульский бизнес» - уникальный инструмент, позволяющий оценить прогресс компании за последний год. Участники премии могут сравнить свои результаты с результатами конкурентов, а в случае победы компания получает стратегическое конкурентное преимущество. Региональная премия «Тульский бизнес» помогает привлекать инвестиции в тульскую экономику. Компаниям, принимающим в ней участие, выпадает уникальный шанс расширить свой бизнес, повысить репутацию и конкурентоспособность, причем не только на рынке Тульской обл., но и в России в целом.

Независимые эксперты премии, а сюда входят ведущие специалисты в области науки и техники Тульского региона, руководители авторитетных общественных организаций дают объективную оценку положения компании на рынке, анализируя ситуацию.

В декабре 2019 г. премия «Тульский бизнес» в 9-й раз подвела бизнес-итоги года в регионе. В мероприятии, проводимом в Доме Дворянского собрания, приняли участие в качестве почетных гостей главный федеральный инспектор по Тульской области, заместители губернатора, мэр г. Тулы, депутаты Госдумы, министры регионального правительства, глава администрации г. Тулы, глава и депутаты областной думы, руководитель Тульского УФАС, руководитель Территориального органа Федеральной службы госстатистики по Тульской области, президент Тульской ТПП, уполномоченный по правам предпринимателей в Тульской области, почетные граждане города-героя Тулы, руководи- 
тели фракций основных политических партий, председатель ТРО ООО МСП «Опора России», генеральный директор Тульского социологического центра. Практически все входят в рейтинг 100 самых влиятельных туляков [Мосин $2013 ; 2014 ; 2018]$. Свои награды получили 27 компаний-лауреатов, отмеченныХ экспертами премии в 2019 г.

Организационным партнером премии «Тульский бизнес», как всегда, было рекламное агентство «Мазов и Ко», а информационными партнерами - сетевое издание «Тульские новости» и «Тульский бизнес-журнал»

Победителями премии «Тульский бизнес 2019» в номинации «Инвестор года» стал ОХК «Шекиноазот»; «Военно-промышленный комплекс года» ПАО «Тульский оружейный завод»; «Машиностроительная компания года» - ООО «Дезинтегратор»; «Строительная компания года» АО Специализированный застройщик «Внешстрой»; «Агропромышленный комплекс года» - ООО «Авиаген»; «Пищевая промышленность» - «Тульский молочный комбинат»; «Тульский бренд» - бренд «Левша», ООО «Первый купажный завод»; «Страховая компания года» - ООО «Страховая Компания «Согласие», Тульский региональный филиал; «Банк года» - Банк ВТБ (ПАО), региональный операционный офис «Тульский»; «За вклад в систему жизнеобеспечения города» - ООО «Хартия», филиал Тульский; «Транспортная компания года» Муниципальное казенное предприятие МО город Тула «Тулгорэлектротранс»; «Автосалон года» - «Nissan КорсГрупп»; «Медицинские услуги» - частное учреждение здравоохранения «Клиническая больница «РЖД-Медицина» города Тула»; «Управляющая компания» - ООО «Фаворит»; «За успешную стратегию в бизнесе» - АКБ «Фора-Банк» (АО), филиал АКБ «Фора-Банк» (АО) в г. Калуге; «Клиентоориентированная компания» - АО МФК Микро Капитал; «За социальную ответственность бизнеса» - филиал ПАО «Квадра» - «Центральная генерация»; «Наиболее динамично развивающаяся компания» - Тульское отделение ПАО Сбербанк; «За высокое качество и сервис» - ООО ГК «Астек Инвест»; «За вклад в развитие строительной отрасли» - ООО «БРАЕР II»; «За реализацию инновационных проектов» - Тульский филиал ПАО «Ростелеком»; «Репутация и доверие» - автономная некоммерческая организация «Клиника микрохирургии глаза «Взгляд»; «Открытие года» - военно-патриотический парк культуры и отдыха «Патриот»; «За вклад в обеспечение здоровья» - Центр стоматологии инновационных технологий им. И.Е. Тихонова; «Потенциал и перспектива» - ООО «Клиника эксперт Тула»; «Народное голосование» - международный фестиваль уличных театров «Театральный дворик»; «Муниципальное образование» - город Тула.

Как видно из списка, победители в номинациях представляют практически все основные отрасли жизнедеятельности Тульской обл. Руководство и жители региона могут ежегодно следить за тем, кто совершенствует свою работу и оказывается в числе победителей, а кто не проявляет должного рвения, и делать из увиденного соответствующие выводы.

\section{Список литературы}

Мосин В.И. 2013. Рейтинг 100 самых влиятельных туляков: методика составления. - Власть. № 5. С. 191-192.

Мосин В.И. 2014. Рейтинг 100 влиятельных туляков - 2013: без сюрпризов не обошлось. - Власть. № 8. С. 148-149.

Мосин В.И. 2018. Рейтинг 100 влиятельных туляков - 2017: стабильность и перемены. - Власть. Т. 26. № 4. С. 158-159. 
MOSIN Vasiliy Ivanovich, Cand.Sci. (Philos.), Associate Professor; General Director of the Tula Sociological Center (of. 39, 28 Garmonnaya St, Tula, Russia, 300001), Senior Researcher at the Center for Regional Historical Research, Tula State Lev Tolstoy Pedagogical University (bld. 4, 125 Lenina Ave, Tula, Russia, 300026; mosin55@bk.ru)

\title{
RELATIONSHIP BETWEEN AUTHORITIES AND BUSINESS IN THE TULA REGION
}

\begin{abstract}
In the article, the author describes the relationship between government and business in the Tula Region on the example of the "Tula Business" annual regional award. In many Russian regions, it is necessary to build a reasonable relationship between business and government. Such a relationship should not harm business development, but on the contrary, help its development for the benefit of the region and Russia as a whole.

The first independent business award "Tula Business" was established in the Tula Region in 2011 with the purpose to summarize the business results of the year. The task is to identify the best companies and create a new image of participating companies. The "Tula Business" annual regional award helps attracting investments in the economy of Tula. Participating companies have a unique chance to expand their business, increase their reputation and competitiveness not only in the Tula Region market, but also in Russia as a whole.
\end{abstract}

Keywords: interconnection, business, authority, award 